\title{
Congenital Disorder of Glycosylation Type IC
}

National Cancer Institute

\section{Source}

National Cancer Institute. Congenital Disorder of Glycosylation Type IC. NCI Thesaurus. Code C126869.

A cong enital disorder of glycosylation sub-type caused by mutation(s) in the ALG6 gene, encoding dolichyl pyrophosphate Man9GlcNAc2 alpha-1,3-glucosyltransferase. 